\title{
Factors Influencing the Implementation of Inclusive Education Policy for People with Different Abilities at Primary School in Bogor, Indonesia
}

\author{
Rizky Defira Mustika ${ }^{1}$, Krisna Puji Rahmayanti ${ }^{2}$ \\ rizkydefiramustika@gmail.com ${ }^{1}, \underline{\text { krisnarahmayanti@ui.ac.id }{ }^{2}}$
}

\begin{abstract}
Department of Public Administration, Faculty of Administrative Science, Universitas Indonesia ${ }^{1}$, Department of Public Administration, Faculty of Administrative Science, Universitas Indonesia ${ }^{2}$
\end{abstract}

\begin{abstract}
The lack and unequal distribution of schools that implement inclusive education policy in Bogor District hampered the opportunity for Children with Special Needs to obtain quality and decent education. This study that aims to describe factors influencing the implementation of inclusive education policy for People with Different Abilities at the elementary schools in Bogor, West Jawa by referring to the theory of Edwards III (1980). This study employs a post-positivist approach with qualitative data collection techniques through in-depth interviews, direct observation, and literature studies with the objects of case study are two elementary schools. Th result shows the policy has not been implemented properly since various obstacles still exist such as uneven understanding of the actors involved; the apparent labeling in the implementation of the policy; the lack of human resources, information, facilities and financial resources; and the low commitment of actors involved in the implementation of inclusive education policy.
\end{abstract}

Keywords: Public Policy; Children with Special Needs; People with Different Abilities; Inclusive Education.

\section{Introduction}

Education in Indonesia has become one of major concerns of development since it is considered as a key investment in human resources. According to Education International, education is a basic right of every human being and is one of the public service products, accessible for the community [1]. In Indonesia alone, the education sector obtains a total of $20 \%$ of the total state budget [2]. A stable budget does not necessarily produce quality education that is evenly distributed throughout Indonesia. The issue of access to education remains felt particularly by Children with Special Needs (CSN) as one of the community groups with the highest dropout rate according to Ubaid Matraji [4]. Therefore, the government made an inclusive education policy, stipulated in the Ministerial Regulation No. 70 of 2009 on Inclusive Education for Persons with Different Abilities, supported by Law No. 8 of 2016 on Persons with Different Abilities. Inclusive education emerges as a response to public phenomenon in the education sector that overlooks students considered to be different from the majority, like those with different abilities [4]. The urgency of implementing inclusive education is to create a quality and fair education system for the community according to national visions as written in the Preamble of the 1945 Constitution. In addition, 
UNESCO [5]. believes that inclusive education aims to create an inclusive society in which community groups like people with different abilities can be an integral part of the wider community that is accepted, inseparable, as well as prioritized. Until now, CSN has not become a priority group in the field of education, including in Bogor District.

Bogor District has been actively implementing the inclusive education policy since 2003 at various levels of the education unit, starting from kindergarten to high school. The Government of Bogor District bases its implementation of inclusive education on Law No 23 of 2003 on National Education System [35], the Regulation of the Minister of National Education No 70 of 2009 on Inclusive Education for Students with Different Abilities and with Special Potential for Intelligence and/or Talent; and the most recent regulation is Law No 8 of 2016 on Persons with Different Abilities [34]. Apart from that, in 2011, the Government of Bogor District confirmed the implementation of inclusive education in its territory through the enactment of the Regulation of Bogor District No 6 of 2011 on the Implementation of Education, in particular Article 32 paragraph (1), as well as the Regulation of Bogor Regent No 27 of 2016 on the Implementation of Special Education in Bogor District. Even though they already have various regulatory bases, according to the Research and Development Unit of Regional Development Agency (Bappedalitbang) of Bogor District, the implementation of inclusive education policy in Bogor District itself has not been carried out systematically [6]. Therefore, in the process of implementing the policy there remain some obstacles.

In terms of the implementation of inclusive education policies for people with different abilities, the various obstacles includes the low quantity of inclusive schools in Bogor District that has not met the number of existing CSN. Up to 2017, of 1,791 primary schools in Bogor District, both state and private, those having implemented inclusive education policy are merely $1.75 \%$ for public schools and $10.8 \%$ for private schools, spread across 11 sub-districts of entirely 40 sub-districts in Bogor District [6]. at the existing percentage, the figure is significantly short to be able to accommodate the entire CSN in Bogor District; particularly since the distribution is not even in all 40 sub-districts. The lack of availability of schools implementing inclusive education has implications on the participation of CSN in education. Up to 2016, 8,877 people have been identified with different abilities in Bogor [7] and based on data at the new elementary school level, $396 \mathrm{CSN}$ are registered and attend regular schools [23].

The next obstacle is the lack of Special Education Teacher (SET) having excellent qualifications to be directly involved in organizing special education for people with different abilities [29]. This encourages many schools providing inclusive education in Bogor District to limit the number of admitted students with special needs. Apart from the lack of human resources, the rejection was also made because in Bogor District, schools providing inclusive education were only prepared to accept mild CSN; while for moderate CSN (like the blind and deaf) are directed to go to Special Schools (SLB) [8]. This condition is contrary to the Regulation of the Minister of Education No 70 of 2009, stating that every school organizing an inclusive education policy must provide at least one seat for CSN in each study group; in addition, the blind and deaf CSN are also included as a type of different abilities supported in inclusive educational policy, hence, they have similar opportunity to go to public school.

The aforementioned various obstacles indicate that the implementation of inclusive education policy in Bogor District has not run well, therefore this study aims to illustrate the impeding factors in the process of implementing inclusive education policy for people with different abilities at primary school education level in Bogor District, West Java Province. 


\section{Literature Review}

This study refers to the theory put forward by [9] regarding the variables that influence policy implementation. This theory was chosen on the basis of conformity with the factual conditions of research context which is inclusive education policy so that researcher can identify the factors contained in the success or failure of the implementation of said policy. Furthermore, this theory was also chosen because the nature of the said policy is a topdown one that was established by the Minister of Education and Culture in 2009. According to [9], there are various factors influencing public policy implementation. These factors consist of four variables, namely communication, resources, disposition and bureaucratic structure. The following is the further elaboration of the said factors.

1) Communication

In general, it discusses the process of transmitting policy content to the relevant organizational personnel because each implementing actor has to understand what they are required to do. Communication is supposed to transpire accurately, clearly and consistently [9]. There are three indicators to measure this variable, namely transmission to discuss the process of channeling information related to the policy to maintain the essence or message expected to be conveyed to all layers of the bureaucracy to minimize the possibility of miscommunication [10]; clarity to emphasize that the policy is clear and unambiguous [10]; and consistency to minimize ambiguous, assumptive, and ineffective policy implementation [9].

2) Resources

Related to the ability of the implementing actors to implement the policy as effectively as possible [10]. According to [9], the resources required in policy implementation consist of four categories, namely adequate and competent human resources as the implementing actors of public policy; information related to the knowledge of the implementing actors regarding the procedures for implementing the policy [9]; authority of the implementing actors to politically carry out their assigned tasks [10]; and facilities, particularly physical facilities such as infrastructure, as supporting resources and a tool to support the successful policy implementation [10]. In this study, the authors attempted to observe the availability of financial resources since they have a high tendency to stimulate the successful policy implementation. Financial resources, according to Appiah-Kubi (2015), have to be strengthened and allocated in a sustainable annual budget. Otherwise, they shall impede the implementation phase.

3) Disposition

Disposition indicates the attitude of the implementing actors related to their willingness to implement policy as mandated by policy makers [11]. There are two ways to overcome the impediment to policy implementation caused by the attitude of the implementing actors, namely the attitude of bureaucrats related to the commitment and dedication to the established policy and public interest and incentive factors. According to [10]. incentives can encourage the performance of the actors in implementing the policy.

4) Bureaucratic structure

A conducive bureaucratic structure is expected to generate a good scope for effective coordination and cooperation among various parties involved in policy implementation [10]. Two elements to stimulate the bureaucratic structure are Standard Operating Procedures (SOP) formulated to enable the parties involved to work according to the applicable performance standards to accomplish quality policy implementation and fragmentation related to the division of responsibilities or tasks among the parties involved in policy implementation. 
This research specifically studies about inclusive education for People With Different Abilities. According to [12]. People With Different Abilities are one of the marginalized groups, they have lower health quality, lower academic achievement, minimal participation in the economy and a higher percentage in poverty compared to non-disabled people. To improve their academic condition, government can implement inclusive education system. Inclusive education can be defined as a process of recognizing and responding to the different needs of all learners through increasing learning participation, culture and society as well as suppressing exclusion in the education sector itself [13]. Basically, inclusive education itself is not only to deal with issues of marginal groups such as People With Different Abilities group that have difficulty accessing education, but is an integral part of the overall education system to achieve sustainable development goals, especially related to quality education for all humanity.

\section{Methods}

This study employed a postpositivist approach that allows the authors to start a study with a theory, then proceed with data collection that can either support or refute the theory, becoming the basis for improvement of the related theory prior to additional testing on the theory [14]. In this study, the authors employed the theory of factors that influence policy implementation by [9] consisting of four variables, namely communication, resources, disposition and bureaucratic structure, serving as the knife for the analysis of this study. The data were collected using qualitative techniques, namely in-depth interviews with 9 informants ranging from the central government, the Government of Bogor District, non-profit institutions, schools, and parents of students with special needs, literature studies and direct observation to two schools implementing inclusive education policy in Bogor District. Those schools were selected based on a purposive sampling technique that was started by considering several relevant criteria namely located in the Greater Jakarta area, has the status as an inclusive school, in primary education level, preferably a prototype of an inclusive school in the region, and have had or are currently accepting students with special needs. The results of the case study analysis do not represent the factual conditions of schools implementing national inclusive education policies in Indonesia or Bogor District itself, because as explained by Flyvbjerg (2006) case study was conducted with the aim of looking deeper into the conditions implementation in schools that are the object of case study only. Through a case study the researcher will get detailed information from the first-level implementor namely the inclusive school. The results of the in-depth interviews were transcribed and categorized in the coding process and then processed using Discourse Network Analyzer (DNA) and Visone software. The data obtained in this study were analyzed based on dimensions, indicators and sub-indicators of the [9] with an ideal type method which compares ideal conditions such as those contained in theory with empirical evidence found in the field [15]. The study was conducted at the Ministry of Education and Culture of the Republic of Indonesia and Bogor District as well as SDN Ciawi 03 and SDN Citapen 01. 


\section{Results}

Policy implementation is part of policy cycle. Van Meter \& Van Horn state that policy implementation cannot be carried out solely by one party [16]. It has to involve various actors, ranging from the central and local governments, private sectors, non-government organizations, advocacy institutions, academics to the general public. A successful policy implementation can be observed from the factors influencing the process, namely communication, resources, disposition and bureaucratic structure [9]. This study analyzed primary data obtained from interviews with 9 informants from central and local governments, non-profit institutions, schools, and parents of students with special needs as well as direct observations to SDN Ciawi 03 and SDN Citapen 01. The results of the in-depth interviews were transcribed into a verbatim report and categorized based on the indicators of the study and the main issues arising in the policy implementation in Bogor District to be processed with DNA and Visone software. The processed data are presented as follows:

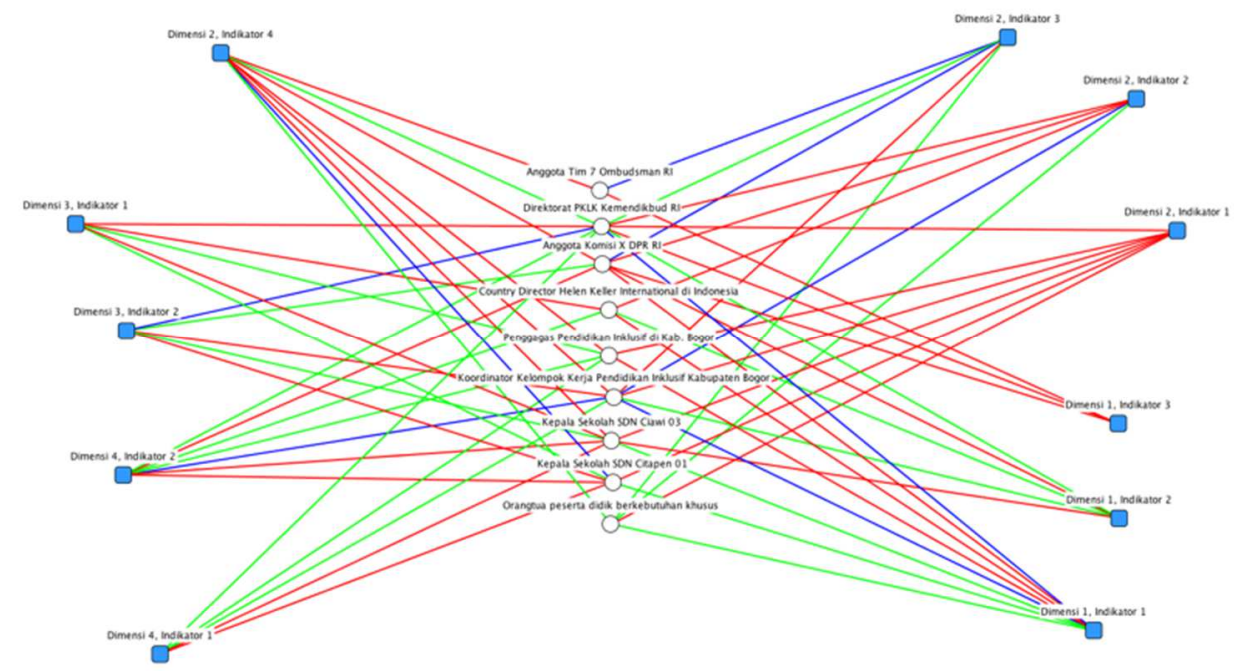

Figure 4.1 The Processed In-depth Interview Data

Source: The processed data using Discourse Network Analyzer and Visone, 2019 The previous figure displays three types of lines in different colors: green and red indicate the agreement and the disagreement of the respondents with the indicators respectively, while blue represents the combination of answers to the indicators, signifying contradictory opinions of the respondents regarding several sub indicators comprising a particular indicator. Of the 11 indicators in this study, none is perfectly accomplished. Despite the complete green lines obtained from all respondents, each indicator has a red and a blue line, meaning that the implementation of inclusive education policy for people with different abilities at primary school level remains experiencing issues that require immediate solution. 
The first variable analyzed is communication. Edwards and Sharkansky argue that an effective policy implementation process is supported by communication between the involved actors [17]. In this regard, the implemented policy has not been based on a common understanding between the implementing actors at the central level and those at the regional level, namely the Government of Bogor District as well as SDN Ciawi 03 and SDN Citapen 01, particularly concerning the vision and context of the inclusive education policy implemented in Indonesia. In terms of the indicator of transmission, the differences in understanding lead to a process of labeling of inclusive education at the level of the Government of Bogor District and schools in Bogor District. As said by UNESCO [18], inclusive education means that the system including all the schools should accommodate the needs of all children regardless of their differences including their physical, social, intellectual, emotional and other condition. Indonesia also has similar vision as that statement, al least for the past decade the government have been trying to involve the on-going condition of all children who are supposedly still in school. The government believes that equal access to education is the key to improve human resource condition in Indonesia.

Furthermore, the implementing actors have not utilized media optimally, resulting in limited communication. However, direct socialization on inclusive education policy has been carried out by the central government to the local government and schools, by the Government of Bogor District to schools in Bogor District, as well as by SDN Ciawi 03 and Citapen 01 to their internal organs, students and parents. In terms of the indicator of clarity, the Government of Bogor District has already established regional regulations referring to the Regulation of the Minister of Education and Culture (Permendikbud) No 70 of 2009, namely Article 32 paragraph (1) of the Regulation of Bogor District No 6 of 2011 on the Implementation of Education and the Regulation of Bogor District No 27 of 2016 on the Implementation of Inclusive Education in Bogor District. The problem is, the existence of these regulations is unknown to schools, including SDN Ciawi 03 and Citapen 01, the leading implementing actors that directly deal with the community. In terms of the indicator of consistency, it is discovered that the content and the objectives of inclusive education policy are not in compliance with various regulations such as Law No 8 of 2016 on People with Different Abilities, as stated by the Ministry of Education and Culture (Kemendikbud) [31]. In addition, other supporting regulations such as those of Special Education Teachers, one of the main elements implementing inclusive education policy in Indonesia, are not consistent with one another. The regulations include the Article 41 paragraph (1) [33], Article 3 and Article 13 paragraph (4) Letter $\mathrm{F}$ of the Regulation of the Minister of Administrative and Bureaucratic Reform (Permenpan RB) No 16 of 2009, and the Regulation of the Minister of National Education (Permendiknas) No 32 of 2008 on Academic Qualification Standards and Competencies for Special Education Teachers.

The second variable analyzed is resources. Adequate and necessary resources have an important role in the implementation of education policies [19]. The first resources are human resources (HR). Human resources are the main resources capable of driving an effective policy implementation process [9]. In the context of inclusive 
education policy for people with different abilities, the required human resources are Special Education Teachers (SET). Based on the opinions of several informants, including the Directorate of PKLK of Kemendikbud RI, members of Commission X of the House of Representatives of Republic of Indonesia (DPR RI), the Inclusive Education Working Group of Bogor District, the Initiator of Inclusive Education in Bogor District, and SDN Ciawi 03 and SDN Citapen 01 (2019), the availability of SET is rather minimal, thus becoming one of the main obstacles in proper policy implementation. The lack of reliable teachers is possibly caused by the fact that Bogor District is dominated by honorary teachers, amounting to approximately 13,000 people [20]. The following graph displays the availability of teachers of public and private elementary schools in Bogor District obtained from the Education Office of Bogor District.

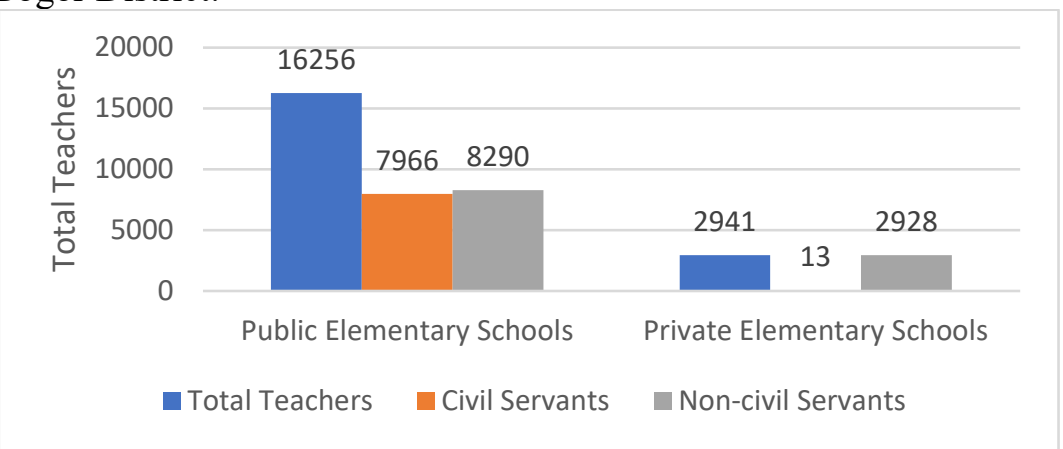

Figure 4.2 The Main Data of the Availability of Teachers in Public and Private Elementary Schools Based on Status in Bogor District in 2013-2014

Source: The Education Office of Bogor District (reprocessed by the authors), 2019.

In addition to having the honorary status, the majority of teachers in Bogor District do not have Special Education educational background and adequate experience in Special Schools. Teachers having attended training are not involved in the process of implementing inclusive education policy in their schools. The training, provided by the government, has not been able to meet the required and demanded competency. Furthermore, SDN Ciawi 03 and Citapen 01 do not have a special teaching team consisting of SET yet.

The second resources are information. Information in the context of policy implementation is related to the knowledge of the implementing actors regarding the procedures for implementing the policy [9]. In the context of Bogor District, the implementation of inclusive education policy remains significantly minimal, particularly in terms of the availability of required data and information. It is caused by several factors. The first factor is the different data criteria due to the different nomenclature/terminology used by each government agency, resulting in partial and segregated process of collecting and processing data. Ministry of Social Affairs and the Social Service of Bogor District use the term "people with different abilities", while the Ministry of Education and Culture and the Education Office of Bogor District use the term "children with special needs" [27]. Moreover, relevant 
information concerning inclusive education policy is not fully open to the public since it is feared that the information shall be used by irresponsible third parties [24]. In addition, the dissemination of information to all implementing actors proceeds slowly since they have to undergo various bureaucratic processes. It is also affected by the vast area of Bogor District, covering 5.19\% of the total area of West Java Province. The Coordinator of the Education Working Group of Bogor District also states, "...the last time we conducted data collection, of 43 available Technical Implementation Units (UPTs) [24], there were only 2 (UPTs) providing data, namely from Cibinong and Ciawi. UPTs are supposed to report schools with children with special needs to Working Group." It indicates the inefficiency and ineffectiveness as well as the lack of participation in the collaboration among the governments of Bogor District and Sub districts regarding inclusive education policy.

The third resources are the authority of the implementing actors. According to Edwards (1980), formal authority is frequently excluded in official documents, thus limiting the mobility of the implementing actors. In practice, there are also various parties at Bogor District having not exercised their authority. The obstacles in exercising this authority are 1) minimal proactive attitude from other official agencies in addition to the Education Office and the Inclusive Education Working Group of Bogor District in implementing inclusive education policy, 2) the fulfillment of the right to education for people with different abilities has not been a priority for the government of Bogor District, hence no effort to internalize authority related to the implementation of inclusive education policy.

The fourth resources are facilities. Based on the Universal Design approach (in Degenhardt \& Schroeder, 2016), the obstacles to access education for children with special needs originate from the physical environment of the school, including infrastructure and the access road to school. Therefore, universal design principles have to be applied to eliminate physical, sensory and cognitive barriers while guaranteeing the aspects of accessibility, usability and security for all students. The availability of facilities is also one of the main issues in the implementation of inclusive education policy in Bogor District, an excuse frequently used by schools to reject children with special needs. Observing the objects of this study, namely SDN Ciawi 03 and SDN Citapen 01, it is proven that the buildings are not universal and fully accessible by all students, including students with special needs. Regarding the access road, SDN Ciawi 03 has a rather serious issue of road infrastructure, since it is merely accessible to pedestrians and two-wheeled vehicles. Moreover, the learning modules tend to be prepared for students without different abilities. Elementary schools at this locus have not yet utilized assistive technology in implementing inclusive education policy.

The fifth resources are financial resources. According to Ikelegbe, the unavailability of resources that meet the needs of the policy implementation process is frequently caused by inaccurate budgeting process carried out by the government [21]. Despite the claim by the central government that a variety of assistance in the context of implementing inclusive education policy has been provided, the Government of Bogor District has so far allocated a budget that is insufficient to 
encourage the implementation of this policy and deemed unable to meet the actual needs. Until now, the Education Office of Bogor District has merely allocated approximately $\mathrm{Rp} 200$ million for teacher training [32], an amount that is considered insufficient. The lack of budget allocations frequently inhibits the enthusiasm of schools in implementing inclusive education policy. Up to this date, the main source of budget used by SDN Citapen 01 is School Operational Assistance (BOS) and assistance from non-profit institutions in partnership with the school. However, the budget allocated by the Government of Bogor District for SDN Ciawi 03 is quite large, particularly that of school construction as well as land acquisition for access road to SDN Ciawi 03.

The third variable is disposition or the attitudes of the actors of policy implementation. Disposition has an important role in ensuring the effectiveness of policy implementation. According to Marume (in Marume, Mutongi, and Madziyire, 2016), the actors involved in a policy are expected to have the desire to carry out the policy implementation to allow an effective and efficient policy implementation. Observing the attitude of the bureaucrats involved as the implementing actors, it is concluded that the Government of Bogor District has not displayed a solid commitment to implement this inclusive education policy. Thus far, the only party from the Government of Bogor District actively attempting inclusive education for people with different abilities is Ms. Hj. Popon Sulistyawati, a former civil servant of the Education Office of Bogor District currently serving in Education UPT of Cibinong Subdistrict, Bogor District. In addition, the leadership of SDN Citapen 01 have displayed their consistency and commitment to proactively implement inclusive education policy since 2012. The incentives to be provided for teaching staff (teachers) by the Government of Bogor District are deemed insufficient and do not meet the needs of the teachers. In fact, the issue of increasing the number of incentives has been discussed since 2018 without any follow-ups.

The last variable is bureaucratic structure. According to Edwards III (1980), the structure of the organizations implementing the policy can influence the policy implementation process. At the central government level, there are various Standard Operating Procedures (SOPs) controlling activities in the process of implementing inclusive education policy, manifested in 16 guidelines for implementing inclusive education from the Directorate of PKLK [22]. At the level of the Government of Bogor District, there are also several SOPs, one of which is regarding the process of rejecting students with special needs by school, as well as work procedures for the Inclusive Education Working Group and the Source Center of Bogor District. However, both SDN Ciawi 03 and SDN Citapen 01 have no formal SOPs specifically addressing the implementation of inclusive education policy. In addition, there has been a clear division of responsibilities at the central government level, particularly within the Ministry of Education and Culture; between the government and various non-profit organizations engaged in inclusive education, such as Helen Keller International and Wahana Inklusif Indonesia in Depok; and in the Government of Bogor District. 


\section{Conclusion}

Based on the aforementioned discussion, it is concluded that the factors influencing the implementation of inclusive education policy for people with different abilities at primary school level in Bogor District have not progressed well. Of the four factors analyzed, the bureaucratic structure is the only accomplished variable. The main issues in implementing inclusive education policy in Bogor District are mainly summarized to the dimension of resources, namely the lack of human resources, the unavailability of information as well as inadequate facilities. Another major issue is communication, in which the implementing actors do not have a common understanding regarding inclusive education policy. Furthermore, policy transmission does not progress well, leading to labelling.

\section{References}

[1] Education International. (2019). Equitable Quality Education: a Precondition for Sustainable Development. From Sustainable Development United Nations: https://sustainabledevelopment.un.org/content/documents/3721 education2.pdf.

[2] Laucereno, S. F. (2018, 07 10). Cerita Sri Mulyani Anggarkan 20\% APBN untuk Pendidikan (Sri Mulyani's Story at Allocating 20\% of The Total State Budget for Education). Retrieved 0126 , 2019 from Detik.com: https://finance.detik.com/berita-ekonomi-bisnis/d-4107156/cerita-srimulyani- anggarkan-20-apbn-untuk-pendidikan

[3] Fadhilah, U. N. (2017, 05 03). Ini Tujuh Masalah Pendidikan di Indonesia Menurut JPPI (These Are Seven Problems of Education in Indonesia Based on JPPI). Retrieved 01 24, 2019 from Republika: $\quad$ https://republika.co.id/berita/pendidikan/eduaction/17/05/03/opchjr354-ini-tujuhmasalah-pendidikan-di-indonesia-menurut-ippi.

[4] Waitoller, F. R., \& Artiles, A. J. (2013, 09). A Decade of Professional Development Research for Inclusive Education: A Critical Review and Notes for a Research Pr. Review of Educational Research, 83(3), 319-356.

[5] Putri, J. K. (2010). Evaluasi Program Penyelenggaraan Pendidikan Inklusif di SDN Kramat Jati 24 dan SDN Kebon Pala 03 Pagi (Evaluation of Inclusive Education Implementation Programs at SDN Kramat Jati 24 and SDN Kebon Pala 03 Pagi). Universitas Indonesia, Public Administration. Jakarta: Universitas Indonesia.

[6] The Research and Development Unit of Regional Development Agency. (2017, 12 5). Memancang Asa Kabupaten Bogor Menjadi Kabupaten Inklusif, Gagasan dan Pengembangan Pendidikan Bagi Difabel (Designing Asa Bogor District to Become an Inclusive Regency, Ideas and Educational Development for Disabled). Retrieved 02, 2019 from the Research and Development Unit of Regional Development Agency: http://bappedalitbang.bogorkab.go.id/topik/memancang-asakabupaten-bogor-menjadi-kabupaten-inklusif-gagasan-pengembangan-pendidikan-bagi-difabel/.

[7] West Java Provincial Statistics Board. (2016). Number of Social Problems by Type in West Java. Bandung: Central Statistics Agency for West Java Province.

[8] NN. (2019, 02, 26). Jumlah SLBN Kurang, ABK Butuh Bantuan Pemkab Bogor (Lack of SLBN Number, ABK Needs Help from Bogor Regency Government). Retrived 07 08, 2019 from Inilahkoran.com: https://www.inilahkoran.com/berita/7387/jumlah-slbn-kurang-abk-butuhbantuan-pemkab-bogor

[9] Edwards III, George C. (1980). Implementing Public Policy. USA: Congressional Quarterly Inc.

[10] Agustino, L. (2014). Dasar-Dasar Kebijakan Publik (The Basics of Public Policy). Bandung: Penerbit Alfabeta

[11] Nugroho, D. R. (2008). Public Policy. Jakarta: PT Elex Media Komputindo. 
[12] World Health Organization. (2017, November). 10 Facts on Disability. From World Health Organization: https://www.who.int/features/factfiles/disability/en/

[13] UNESCO. (2005). Guridelines for Inclusion: Ensuring Access to Education For All . Paris: UNESCO.

[14] Creswell, J. W. (2014). Research Design: Quantitative, Qualitative, and Mixed Methods Approaches. United States: SAGE Publication.

[15] Neuman, W. L. (2014). Social Research methods: Qualiative and Quantitative Approaches. England: Pearson.

[16] Khan, A. R. (2016). Policy Implementation: Some Aspects and Issues. Journal of Community Positive Practice, XVI(3), 3-12.

[17] Marume, D. S., Mutongi, D., \& Madziyire, N. (2016). An Analysis of Public Policy Implementation. IOSR Journal of Business and Management (IOSR-JBM), 18(4), 86-93.

[18] Pizzuto, S. A. (2010). A Teacher, A Classroom, A School: Holistic Approach Towards Inclusion. In D. A. Azzopardi, Making sense of inclusive education: Where everyone belongs (pp. 87-94). United Kingdom: VDM Verlag Dr. Müller.

[19] Stubbs, S. (2008). Inclusive Education Where There are Few Resources. Oslo, Norway: The State Alliance.

[20] bogor-kita.com. (2018, 11 29). Bogor Kita. Retrieved 06 09, 2019 from DPRD Kabupaten Bogor Bahas Kesejahteraan 13.000 Guru Honorer Jadi Rp2 Juta Per Bulan: https://bogor-kita.com/dprdkabupaten-bogor-bahas-kesejahteraan-13-000-guru-honorer-jadi-rp2-juta-per-bulan/.

[21] Ikechukwu, Dr. Ugwuanyi Bartholomew. (2013). ᄀThe Obstacles to Effective Policy Implementation by the Public Bureaucracy in Developing Nations: The Case of Nigeria. Singaporean Journal of Business Economics and Management Studies, 1 (8), 34-34.

[22] The Directorate of Special Education and Special Services (PKLK) for Elementary School of Kemendikbud RI. (2013). Pedoman Umum Penyelenggaraan Pendidikan Inklusif sesuai Permendiknas No 70 Tahun 2009 (General Guidelines for the Implementation of Inclusive Education (in accordance with Ministry of Education Regulation No. 70 of 2009). DKI Jakarta: The Directorate of Special Education and Special Services (PKLK) for Elementary School of Kemendikbud RI.

[23] The Inclusive Education Working Group of Bogor District. (2017). Validasi Data Sekolah Penyelenggara Pendidikan Inklusif di Kabupaten Bogor Tahun 2017/2018 (Data Validation of Inclusive Education Provider Schools in Bogor Regency in 2017/2018).

[24] Mr. Abdul Hakim Ashory, the Coordinator of the Inclusive Education Working Group of Bogor District, May 23, 2019, In-depth Interview.

[25] Mr. Misbah, the Principal of SDN Citapen 01, May 21, 2019, In-depth Interview.

[26] Mr. Yusuf Iskandar, the Principal of SDN Ciawi 03, May 9, 2019, In-depth Interview.

[27] Ms. Emilia Kristiyanti, Country Director of Helen Keller International, May 29, 2019, In-depth Interview.

[28] Ms. Hj. Ledia Hanifa, a Member of Commission X of the House of Representatives of Republic of Indonesia (DPR RI), May 24, 2019, In-depth Interview.

[29] Ms. Hj. Popon Sulistyawati, the Initiator of Inclusive Education in Bogor District, May 20, 2019, In-depth Interview.

[30] Ms. Susi, the parent of deaf student with special needs, May 21, 2019, In-depth Interview.

[31] Ms. Tita Sriharyati, the Head of Subdirectorate of Curriculum, the Directorate of PKLK Kemendikbud RI, May 27, 2019, In-depth Interview.

[32] The Education Office of Bogor District. (2019). Kondisi Data Pokok Pendidikan tahun 2013-2014 (Basic Education Data for 2013-2014. http://disdik.bogorkab.go.id/index.php/multisite/page/308data-pokok-pendidikan accessed on July 3, 2019.

[33] The Government Regulation No 19 of 2005 on National Education Standards.

[34] Law No 8 of 2016 on People with Different Abilities

[35] Law No 20 of 2003 on National Education System

[36] The Regulation of the Minister of Administrative and Bureaucratic Reform (Permenpan RB) No 16 of 2009 on Teacher's Functional Position and Credit Score. 
[37] The Regulation of the Minister of Education and Culture (Permendikbud) No 14 of 2018 on Acceptance of New Students in Kindergartens, Elementary Schools, Junior High Schools, Senior High Schools, Vocational High Schools or Other Equivalents.

[38] The Regulation of the Minister of National Education (Permendiknas) No 32 of 2008 on Academic Qualification Standards and Competencies for Special Education Teachers

[39] The Regulation of the Minister of National Education (Permendiknas) No 70 of 2009 on Inclusive Education of People with Different Abilities. 